\title{
RESIDUAL EFFECT OF GROWTH REGULATORS IN ETIOLATION AND REGENERATION OF IN VITRO PINEAPPLE PLANTS ${ }^{1}$
}

\author{
FERNANDA VIDIGAL DUARTE SOUZA², ANA MARIA MASCARENHAS ELOY CANTO, \\ ANTÔNIO DA SILVA SOUZA², MARIA ANGÉLICA PEREIRA DE CARVALHO COSTA ${ }^{4}$
}

\begin{abstract}
This work aimed to evaluate the influence of naphthaleneacetic acid (NAA) and gibberellic acid $\left(\mathrm{GA}_{3}\right)$ plant regulators in in vitro etiolation and subsequent regeneration of the PE x SC-60 pineapple hybrid. Nodal segments of in vitro plants with approximately $5-7 \mathrm{~cm}$ height were incubated in basic MS culture medium supplemented with $0.0 ; 0.5$ and $1.0 \mathrm{mg} \mathrm{L}^{-1}$ of naphthaleneacetic acid (NAA) in combination with gibberellic acid $\left(\mathrm{GA}_{3}\right)$ in concentrations of $0.0 ; 0.5$ and $1.0 \mathrm{mg} \mathrm{L}^{-1}$, and maintained at $27^{\circ} \mathrm{C} \pm 1{ }^{\circ} \mathrm{C}$ under dark condition. Evaluations were carried out at 90 and 180 days after incubation period. The best results for length of etiolated stems were obtained with $1.0 \mathrm{mg} \mathrm{L}^{-1}$ of NAA. In the experiment followed by the regeneration, stems with $3 \mathrm{~cm}$ from the etiolation treatment, were cultivated in proliferation medium and the number of regenerated plants per treatment was evaluated at 60 days of cultivation. The treatment that promoted the best etiolation of plants also promoted the worst regeneration rates, demonstrating the residual effect of the auxin used in the previous step in the regeneration of plants of the pineapple hybrid evaluated. Index terms: Ananas comosus var. comosus, in vitro culture, plant regulators, nodal segments, germplasm conservation, micropropagation.
\end{abstract}

\section{EFEITO RESIDUAL DE REGULADORES DE CRESCIMENTO NO ESTIOLAMENTO E REGENERAÇÃO DE PLANTAS DE ABACAXI IN VITRO}

RESUMO-O objetivo deste trabalho foi avaliar a influência dos reguladores vegetais ácido naftalenoacético (ANA) e ácido giberélico $\left(\mathrm{AG}_{3}\right)$ no estiolamento in vitro e posterior regeneração de plantas do abacaxizeiro híbrido PE x SC-60. Segmentos nodais de plantas produzidas in vitro, com aproximadamente 5-7 cm de comprimento, foram incubados em meio de cultura MS em sua concentração básica, suplementados com 0,$0 ; 0,5$ e 1,0 $\mathrm{mg} \mathrm{L}^{-1}$ de ácido naftalenoacético (ANA) em combinação com ácido giberélico $\left(\mathrm{AG}_{3}\right)$, nas concentrações de 0,$0 ; 0,5$ e $1,0 \mathrm{mg} \mathrm{L}^{-1}$, e mantidos a $27^{\circ} \mathrm{C} \pm 1^{\circ} \mathrm{C}$ e sob condições de escuro. As avaliações foram realizadas aos $90 ; 180$ dias de incubação. Os melhores resultados foram obtidos com a concentração de $1,0 \mathrm{mg} \mathrm{L}^{-1}$ de ANA. No experimento posterior de regeneração, hastes com $3 \mathrm{~cm}$, oriundas dos tratamentos de estiolamento, foram cultivadas em meio de proliferação, quando aos 60 dias de cultivo avaliou-se o número de plantas regeneradas por tratamento. $O$ tratamento que resultou ser mais efetivo para o estiolamento das plantas foi o que apresentou maior dificuldade de regeneração, demonstrando o efeito residual do regulador auxina na regeneração de plantas de híbrido de abacaxi.

Termos para indexação: Ananas comosus var. comosus, cultura in vitro, reguladores vegetais, segmentos nodais, conservação de germoplasma, micropropagação.

${ }^{1}$ (Trabalho 075-09). Recebido em: 03-04-2009. Aceito para publcação em: 27-11-2009.

${ }^{2}$ D.Sc.Researchers of Embrapa Cassava and Tropical Fruits, Cruz das Almas-BA, E-mail: fernanda@cnpmf.embrapa.br; assouza@cnpmf.embrapa.br

${ }^{3}$ Master Student of UFRB (Federal University of Recôncavo da Bahia), Cruz das Almas-BA. anaeloy@hotmail.com

${ }^{4}$ Professor of UFRB (Federal University of Recôncavo da Bahia), Cruz das Almas -BA. E-mail: mapcosta@ufrb.edu.br 
Pineapple propagation is mainly asexual and the conventional method of plantlet production is through lateral buds and presents a very low multiplication rate (REINHARDT; CUNHA, 1999).

Biotechnology applied to plantlet production using in vitro tissue culture enables the introduction of a hybrid in the market in a very short period of time. In pineapple, laboratory plantlet production has already been carried out with success through micropropagation, obtaining a large number of plants with guaranteed phytosanitary conditions.

The use of nodal segments as explants for micropropagation and conservation of genetic stability has been shown in pineapple (KISS et al., 1995; BARBOZA ; CALDAS, 2001; MOREIRA et al., 2003). In pineapple, this type of explant is obtained through etiolation of in vitro plants with the advantage of avoiding injuries in the regeneration region and avoiding callus formation and consequently genetic variation. Additionally, the use of nodal segments can be an interesting strategy to increase multiplication rates. Moreira et al. (2003), evaluating multiplication rates of the Pérola cultivar through shoot etiolation, found the best results for length of etiolated shoots as well as for number of buds, using the MS medium supplemented with NAA at $1.8 \mathrm{mg} \mathrm{L}^{-1}+\mathrm{BAP}$ at $2.0 \mathrm{mg} \mathrm{L}^{-1}$. Similar results were encountered by Barboza e Caldas (2001) with the PE x SC-52 hybrid; both works showing the viability of multiplying pineapple in vitro using nodal segments as the initial explant. It is worth noting, however, that the length of the etiolated shoots is an important variable and can be straightly related with the number of nodal segments to be cultivated in multiplication medium.

The adequate use of auxins and gibberellins can promote greater lengthening of the stems leading to division stimulation and cell elongation. Auxins are essential plant growth regulators since they act in the regulation of distinct programs of cell development by affecting growth, division and cell development (CALLIS, 2005). Gibberellins have been considered as a plant growth regulator acting at the endogenous level controlling many plant growth and development aspects such as stem elongation, root and fruit development. Although these regulators have being used for etiolation of pineapple stems, the residual effect in the multiplication rates are still unknown (BARBOZA; CALDAS, 2001; MOREIRA et al., 2003).

This work aimed to evaluate the influence of naphthaleneacetic acid (NAA) and gibberellic acid $\left(\mathrm{GA}_{3}\right)$ growth regulators in the length and number of nodal segments of etiolated stems and the possible residual effects in subsequent in vitro regeneration of pineapple hybrid plants.

It was used plants of the PE x SC-60 (Perolera $\mathrm{x}$ Smooth Cayenne) hybrid, regenerated in vitro in MS medium from auxiliary buds. To etiolation experiments in vitro plants from auxiliary buds were reduced to approximately $1 \mathrm{~cm}$ after leaf removal, remaining the stem to homogenize the starting material. The culture medium used was the MS (MURASHIGE; SKOOG, 1962), supplemented with de $30 \mathrm{~g} \mathrm{~L}^{-1}$ of sucrose, $0.0 ; 0.5$ and $1.0 \mathrm{mg} \mathrm{L}^{-1}$ of naphthaleneacetic acid (NAA) in combination with gibberellic acid $\left(\mathrm{GA}_{3}\right)$ in the following concentrations: $0.0 ; 0.5$ and $1.0 \mathrm{mg} \mathrm{L}^{-1}$, solidified with $8 \mathrm{~g} \mathrm{~L}^{-1}$ of agar, $\mathrm{pH}$ adjusted to 5.8 , incubated under dark condition and temperature of $27 \pm 1^{\circ} \mathrm{C}$. The experimental design was completely randomized in $3 \times 3$ factorial schemes with 30 repetitions considering one explant per $150 \mathrm{~mm}$ x $25 \mathrm{~mm}$ test tube containing $15 \mathrm{~mL}$ of culture medium. Evaluations were carried out 90 and 180 days after incubation considering the following variables: a) stem length and b) number of buds per stem.

To regeneration and micropropagation of plants, apex and root from etiolated plants were removed. Five segments per stem were used, placed in Magenta ${ }^{\mathrm{TM}}$ containing $70 \mathrm{~mL}$ of the MS culture medium $+0.01 \mathrm{mg} \mathrm{L}^{-1}$ of NAA and $0.02 \mathrm{mg} \mathrm{L}^{-1}$ of BAP; $30 \mathrm{mg} \mathrm{L}^{-1}$ sucrose and agar, $8 \mathrm{~g} \mathrm{~L}^{-1}$. The material was incubated in growth chamber with light intensity of $22 \mu \mathrm{E} \mathrm{m}^{-2} \mathrm{~s}^{-1}$, temperature of $25 \pm 2{ }^{\circ} \mathrm{C}$ and 16 hour photoperiod. The evaluation of the number of plants per stem was carried at 60 days of cultivation. The analysis of variance was carried out to study the variables of both experiments and the averages compared by the Tukey test at $5 \%$ probability. The SAS software package (SAS INSTITUTE INC., 2000) was used for the statistical analysis. For the variables number of buds per etiolated stem and number of regenerated plants, the transformation $\sqrt{\mathrm{x}+0,5}$ was necessary in order to correct deviations in the normal distribution of the data.

In vitro pineapple stem length at 90 and 180 days of cultivation varied according to the plant growth regulators; the concentrations and the combinations between them (Table 1). Longer stems at 90 days of cultivation were obtained in the medium containing $1.0 \mathrm{mg} \mathrm{L}^{-1}$ of NAA (T07), whereas the treatments that contained only $\mathrm{GA}_{3}$ produced smaller stems (T02). An increasing and significant growth of the stems was observed once the treatments with $\mathrm{GA}_{3}$ were combined with NAA, with the increase of NAA dosages, indicating the beneficial effect of this growth regulator in plant elongation. 
At 180 days this behavior was practically the same whereas the treatment with $0.5 \mathrm{mg} \mathrm{L}^{-1}$ of NAA (T04) promoted as good results as those promoted by T07 with $1.0 \mathrm{mg} \mathrm{L}^{-1}$ of NAA.

On the other hand, in the second period of evaluation, the control group presented a greater value in relation to the treatments which only $\mathrm{GA}_{3}$ was added to the medium, suggesting an inhibitory mode of action of this regulator in stem elongation, as well as probable endogenous synthesis of a plant regulator responsible for plant etiolation of the control group, which certainly is an auxin and most probably, IAA, the most abundant auxin in plants (WOODWARD; BARTEL, 2005).

Mercier et al (2003), evaluating the in vitro organogenetic response of pineapple leaves in medium without the supplementation of plant regulators, verified that the endogenous balance of auxin and cytokinin in the third day of cultivation reduced, whereas at 15, a similar balance occurred between the control group and the medium supplemented with plant regulators, which could only have happened by the endogenous synthesis of these regulators.

Regarding to $\mathrm{GA}_{3}$ response, at least for the concentrations used in this study, the effects that this regulator has over the auxins needs to be evaluated. The use of exogenous gibberellins in plant tissue leads to an increase in the endogenous levels of auxins and consequently to elongation of stems in many species (VALDOVINOS et al., 1967), therefore, its use was questioned during this work. However, the stimulation caused by the use of this regulator was non-expressive or inexistent as can be seen in the results. The explanation could be its high sensitivity to light and, as observed in some in vivo species, its synthesis can be inhibited by shorter days. Under in vitro and dark conditions, as in this work, inactivation of $\mathrm{GA}_{3}$ added to the medium might have happened, as well as an inhibitory effect, as mentioned earlier, if we consider the results observed in the control group.

Stem length is just as important as the number of nodes or nodal segments that are generated by these treatments, since these are the structures that will serve as explants for subsequent multiplication of this material. Therefore, the influence of these treatments in the formation of nodal segments, as well as its correlation with the length variable, were evaluated. These evaluations were equally carried out at 90 and 180 days after cultivation, and the results are shown in Table 2.

Regarding to nodal segment formation, the best results were the ones obtained by the treatments that presented longest stem length. The greater number of segments was achieved by the $1.0 \mathrm{mg} \mathrm{L}^{-1}$ of
NAA medium, 9.63 and 23.03 at 90 and 180 days, respectively.

These results differ from those reported by Kiss et al. (1995), with the Smooth Cayenne cultivar in medium containing $1.86 \mathrm{mg} \mathrm{L}^{-1}$ of NAA, obtaining an average of 7.0 buds per etiolated stem in a period of approximately 35 days, corresponding to approximately $1 / 3$ of the cultivation period established in this work. Barboza \& Caldas (2001) also verified the efficiency of NAA in shoot etiolation of the PE x SC-52 pineapple hybrid, obtaining 11.3 nodal segments per etiolated shoot at 60 days of cultivation. The fact that these authors used a greater NAA concentration than the one used in this work, as well as a probable effect of the genotype, could explain the greater number of nodal segments encountered by them in a smaller cultivation period.

Therefore, it was observed that the number of nodal segments formed corresponded to the lengths obtained for the stems; whereas, the longer the stem, the greater the number of segments obtained, characterizing a straight relationship between both variables. It is possible to state, therefore, that the different treatments did not influence the distance between the nodes, which certainly could generate a different result.

Concerning plant regeneration from nodal segments obtained through the different etiolation treatments, the results demonstrated that the best media for stem etiolation, therefore, those containing only NAA in the cultivation medium, presented the lowest plant regeneration rate (Figure 1). The highest plant regeneration averages were obtained with the media containing $0.5 \mathrm{mg} \mathrm{L}^{-1}(5.8)$ and $1.0 \mathrm{mg} \mathrm{L}^{-1}$ (5.5) of $\mathrm{GA}_{3}$ and in the absence of NAA, suggesting a strong residual effect of auxin, mostly due to the long cultivation period in etiolation medium, and considering that the apical dominance was broken by cutting the apex of the stems. This residual effect can be explained by the regulation of the endogenous levels of cytokinin, carried out by the auxins, either by inhibition of cytokinin biosynthesis or by the promotion of metabolic inactivators such as cytokinin oxydase. The effect can be the reduction of the flow of this regulator towards the shoots, interfering therefore, in shoot development (CALLIS, 2005). The results obtained with the control group $(4,2$ plant/nodal segment) are in agreement with this suggestion. Souza et al. (2003), working with pineapple nodal segments, evaluated the relationship between the levels of endogenous auxins and cytokinin and its relationship to stem auxiliary bud development. It was shown that the beginning of shoot development is related to drastic initial reduction of the levels of 
IAA, therefore decreasing the IAA/cytokinin ratio suggesting that this event could be the signal for dominant apex breakage, demonstrating the effective action of auxins throughout the entire process. Barboza and Caldas (2001), using nodal segments of the PE x SC 52 pineapple hybrid and evaluating multiplication rates in different cultivation media, obtained the best results in media without auxin supplementation.

The in vitro plant etiolation has been an interesting strategy for pineapple microprogation, as reported (BARBOZA; CALDAS, 2001; SOUZA et al., 2003). The initial proposal, carried out by Kiss et al. (1995), used this methodology only aiming at genetic stability in pineapple in vitro propagation mainly due to somaclonal variation. The methodology has been efficient for multiplication but there are no published results regarding genetic stability of nodal segments in relation to in vitro multiplication by auxiliary buds. This method, however, has been tested for many varieties or new hybrids, as well as for wild pineapple varieties which are difficult in responding to traditional protocols. The use of regulators during the etiolation stage has been reported, without, however, considering its residual effects. This work demonstrated that the use of these regulators influenced the subsequent step of plant regeneration and that the use of auxins in the etiolation phase should be avoided.

TABLE 1 - Average length (LS) and Number of buds (NB) of etiolated stems from the PE x SC-60 pineapple hybrid at 90 and 180 days after cultivation.

\begin{tabular}{|c|c|c|c|c|c|c|c|c|c|}
\hline & & & \multicolumn{6}{|c|}{$\mathrm{GA}_{3}\left(\mathrm{mg} \mathrm{L}^{-1}\right)$} & \multirow{3}{*}{$\mathrm{CV}(\%)$} \\
\hline & & & \multicolumn{2}{|c|}{0.0} & \multicolumn{2}{|c|}{0.5} & \multicolumn{2}{|c|}{1.0} & \\
\hline & & & LS & NB & LS & NB & LS & NB & \\
\hline \multirow{4}{*}{$\begin{array}{c}90 \\
\text { days }\end{array}$} & \multirow{6}{*}{$\begin{array}{c}\text { NAA } \\
\left(\mathrm{mg} \mathrm{L}^{-1}\right)\end{array}$} & 0.0 & $5.37 \mathrm{abC}$ & $4.53 \mathrm{aB}$ & $4.30 \mathrm{bC}$ & $5.60 \mathrm{aA}$ & $6.25 \mathrm{aB}$ & $6.28 \mathrm{aA}$ & \multirow{3}{*}{$\begin{array}{c}37.63 \\
(\mathrm{LS}) \\
37.95 \\
(\mathrm{NB})\end{array}$} \\
\hline & & 0.5 & $7.00 \mathrm{abB}$ & $5.23 \mathrm{aB}$ & $6.13 \mathrm{bB}$ & $4.24 \mathrm{aA}$ & $7.68 \mathrm{aAB}$ & $6.93 \mathrm{aA}$ & \\
\hline & & 1.0 & $9.71 \mathrm{aA}$ & $9.63 \mathrm{aA}$ & $8.01 \mathrm{bA}$ & $5.19 \mathrm{bA}$ & $7.81 \mathrm{bA}$ & $6.23 \mathrm{aB}$ & \\
\hline & & 0.0 & $13.21 \mathrm{aB}$ & $16.21 \mathrm{aB}$ & $10.58 \mathrm{aB}$ & $17.51 \mathrm{aA}$ & $11.67 \mathrm{aA}$ & $14.42 \mathrm{aA}$ & \multirow{3}{*}{$\begin{array}{c}36.03 \\
(\mathrm{LS}) \\
32.34 \\
(\mathrm{NB})\end{array}$} \\
\hline \multirow[t]{2}{*}{$\begin{array}{l}180 \\
\text { days }\end{array}$} & & 0.5 & $17.20 \mathrm{aA}$ & $21.51 \mathrm{aA}$ & $13.07 \mathrm{AB}$ & $17.63 \mathrm{aA}$ & $12.90 \mathrm{bA}$ & $17.45 \mathrm{aA}$ & \\
\hline & & 1.0 & $16.00 \mathrm{aAB}$ & $23.03 \mathrm{aA}$ & $13.54 \mathrm{aA}$ & $17.15 \mathrm{aA}$ & $12.94 \mathrm{aA}$ & $17.71 \mathrm{aA}$ & \\
\hline
\end{tabular}

Means followed by the same lower case letters in the rows and upper case letters in the columns, for each period of evaluation, do not differ by the Tukey test at $5 \%$ probability. 


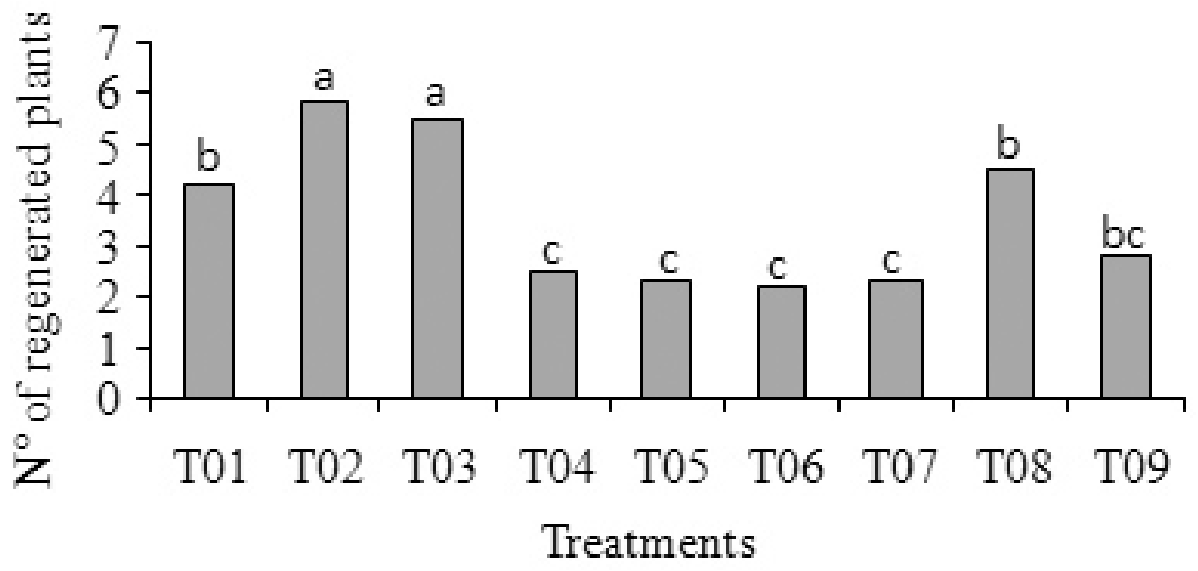

FIGURE 1 - Number of plants regenerated from nodal segments of the PE x SC-60 pineapple hybrid 60 days after cultivation. The treatments were labeled as: $\mathrm{T} 01$ - Control; $\mathrm{T} 02-0.5 \mathrm{mg} \mathrm{L}^{-1} \mathrm{GA}_{3}$; T03 - $1.0 \mathrm{mg} \mathrm{L}^{-1} \mathrm{GA}_{3}$; $\mathrm{T} 04-0.5 \mathrm{mg} \mathrm{L}^{-1} \mathrm{NAA}$; $05-0.5 \mathrm{mg} \mathrm{L}^{-1} \mathrm{NAA}+0.5 \mathrm{mg} \mathrm{L}^{-1} \mathrm{GA} 3$; T06 -0.5 mg L ${ }^{-1} \mathrm{NAA}+1.0 \mathrm{mg} \mathrm{L}^{-1} \mathrm{GA}_{3}$; $\mathrm{T} 07-1.0 \mathrm{mg} \mathrm{L}^{-1} \mathrm{NAA}$; $\mathrm{T} 08-1.0 \mathrm{mg} \mathrm{L}^{-1} \mathrm{NAA}+$ $0.5 \mathrm{mg} \mathrm{L}^{-1} \mathrm{GA}_{3}$; $\mathrm{T} 09-1.0 \mathrm{mg} \mathrm{L}^{-1} \mathrm{NAA}+1.0 \mathrm{mg} \mathrm{L}^{-1} \mathrm{GA}_{3}$.

\section{CONCLUSION}

1-The presence of NAA in the medium culture improves the stem elongation and the number of nodal segments.

2-The number of nodal segments formed corresponded to the lengths obtained for the stems.

3 -The use of NAA in the etiolating stage presented negative effect to the multiplication stage.

4-The use of GA3 in the etiolating stage promoted the highest multiplication rates in the subsequence stage.

\section{REFERENCES}

BARBOZA, S. B. S. C.; CALDAS, L. S. Estiolamento e regeneração na multiplicação in vitro do abacaxizeiro híbrido PE x SC-52. Pesquisa Agropecuária Brasileira, Brasília, v. 36, n. 3, p.417-423, 2001.

CALLIS, J. Plant biology: auxin action. Nature, London, v.435, n. 7038, p. 436-437, 2005.

DEWALD, M. G.; MOORE, G. A.; SHERMAN, W. B.; EVANS, M. H. Production of pineapple plants in vitro. Plant Cell Reports, Berlin, v. 7, n. 7, p. 535537, 1988.
KISS, E.; KISS, J.; GYULAI, G.; HESZKY, L. E. A novel method for rapid micropropagation of pineapple. HortScience, Alexandria, v. 30, n. 1, p. 127-129, 1995.

MAYNARD, B.K.; BASSUK, N.L. Effects of stock plant etiolation, shading, banding, and shoot development on histology and cutting propagation of Carpirus betulus L. fastigiata. Journal of American Society for Horticultural Science, Madison, v.121, n.5, p.853-860, 1996.

MERCIER, H.; SOUZA, B.M.; KRAUS, J.E.; HAMASAKI, R.M.; SOTTA, B. Endogenous auxin and cytokinin contents associated with shoot formation in leaves of pineapple cultured in vitro Brazilian Journal Plant Physiology, Campos do Goytacazes, n.15, v.2. p.107-112, 2003.

MOREIRA, M.A.; PASQUAL, M.; CARVALHO, J.G.; FRÁGUAS, C.B. Estiolamento na micropropagação do abacaxizeiro 'Pérola'.Ciência e Agrotecnologia, Lavras, v.27, n.5, p. 1002-1005. 2003.

MURASHIGE, T. ; SKOOG, F.M. A revised medium for rapid growth and biossays with tobacco tissue cultures. Physiologia Plantarum, Copenhagen, v.15, p.473-497, 1962 
REINHART, D.H.; CUNHA, G.A.P da. Métodos de propagação. In: CUNHA, G.A.P da; CABRAL, J.R.S.; SOUZA, L.F. da S. (Org.). O abacaxizeiro: cultivo, agroindústria e economia. Brasília: Embrapa Comunicação para Transferência e Tecnologia, 1999. p.105-138.

SAS INSTITUTE. SAS/STAT user's guide: v. 8.0. Cary, 2000. v.1-3.
SOUZA, B. M.; KRAUS, J. E.; ENDRES, L.; MERCIER, H. Relationships between endogenous hormonal levels and axillary bud development of Ananas comosus nodal segments. Plant Physiology and Biochemistry, Paris, v. 41, n. 8, p. 733-739, 2003.

VALDOVINOS, J.G.; ERNESTS, L.C.;HENRY, E.W. Effect of ethylene and giberelic acid on auxin syntesis In plant tissues. Plant Physiology, Rockville, v.42, n.12, p. 1803-1806, 1967.

WOODWARD, A.W.; BARTEL, B. Auxin: regulation, action, and interaction. Annals of Botany, London, v.95, n.5, p.707-735, 2005. 